\title{
Towards a Sociology of Trust: Community Care and Managing Diversity
}

\author{
Jason L. Powell \\ University of Central Lancashire, Lancashire, UK \\ Email: J.L.Powell@liverpool.ac.uk \\ Received January 21 $1^{\text {st }}, 2011$; revised January $25^{\text {th }}, 2011$; accepted January $29^{\text {th }}, 2011$.
}

\begin{abstract}
The paper is a critical review of the problems and implications of managing diversity in the British community care system. It is a system in need of strong diversity management in the light of the world economic downturn in recent years. Despite raft of policies on leadership in social care in the UK, the structural issues for why the needs of diverse groups are not met are difficult to understand at particular levels of analysis. The central problem has been lack of "trust".
\end{abstract}

Keywords: Community, Care, Trust, Sociology and Social Welfare

\section{Introduction}

Community Care legislation has in the past decade received scantily uncritical sociological acclaim. Community care policy based on the triumvirate of "autonomy", "empowerment" and "choice" was endorsed by many commentators as the political and philosophical panacea for alleviating the deep and destructive problems confronting the community care system in the UK (Powell, 2009). This paper deconstructs the hagiography surrounding community care policy. The broken relationship between professionals and older people has been placated on distrust. A close and cogent examination of the emergence of community care policy in the UK raises serious questions about its main intentions. Whose account was to count in the formulation and implementation of community care policy was based on a hierarchical vision of care truth in which the definition of reality articulated by older people was secondary to reality defined by "experts"/state servants such as policy advisors. In other words, it is "expert" led with no understanding of diversity and experiences of users.

This is not the place to explore the epistemological and ontological debates concerning definitions of reality that have developed in social gerontology in recent years (Biggs \& Powell, 2000). However, it is important to note that community care policy fails to convey in any strong sense alternative definitions of truth or different visions of care truth based on older people's subjective experiences (Biggs \& Powell, 2000). Rather, the agism of community care policy has perpetually directed its gaze downwards towards older people thus reinforcing "an overall impression that these are the people who need to be researched, these are the ones who are out of step with 'social norms' or who are causing the problems" (Smart, 1984, pp. 150-151). Conversely, community care policy rarely gazes upwards to look at "the locally powerful" (Smart, 1984) who in the case of older people would be care managers. The lack of any critical analysis of the role and daily practices of care managers constitutes a major weakness of the implementative process of the policy process in the UK in terms of accountability and sensitisation of diversity in managerial philosophy and practice.

The confusion and conflict between different state servants over the past 20 years provide clear illustrations of the fractured dislocation within the state concerning community care policy and muddled issues relating to managing diversity. However, it also leads the space, whether imaginative or experiential, by which care managers and older people interact. It is within that space that an understanding of "trust" is the missing cement to bind relationships based on managing diversity. "Trust" itself is an essentially contested concept. Trust can extend to people with a sense of shared identity (Gilson, 2003; Tulloch \& Lupton, 2003). Individuals produce trust through experience and over time. It cannot be immediately and with purpose be produced by organizations or governments without dialogical interaction with people on issues affecting their lifestyles and life-chances such as care, pensions, employment and political representation (Walker \& Naeghele, 1999). Möllering (2001) takes the relational theme further by distinguishing between trust in contracts between individuals and the State in areas such as pension provision; trust in friendships across intergenerational lines; trust in love and relationships, and trust in foreign issues associated with national identity. There is a multiplicity of ways that trust has been defined but the central paradox is how to creation of the conditions of building conditions of trust across personal-organisational-structural tiers in an increasingly uncertain world. The chapter explores community care policy and navigates the ways trust relations can capture stronger bonds and relationships between care managers and user groups such as older people in the UK.

\section{Community Care in the UK}

\section{Contextual Backdrop}

Contemporary community care policy emerged due to three significant factors during the dominance of the Conservative administration in the UK from 1979 onwards and has seen a resurgence in 2010 with more "financial reforms" in light of world economic recession. Firstly, one of the central planks of 
UK government policy throughout the 1980's was the genesis of marketisation into the public sector. Government reforms in education and the health service, for example, constructed a quasi-market with internal commissioning and provider roles to stimulate the "buying" and "selling" of in-house services (Means \& Smith, 1997). Simultaneously, new legislation required local authorities to embark upon a phased programme, determined by central government, through which many of its services had to be subjected to compulsory competitive tendering, with the strategy of decreasing the role of local authorities and stimulating instead the private sector. The value which underpins all of these policy initiatives is a belief that a competitive market and a "mixed economy of welfare" will inevitably provide better, cheaper services than a protected and bureaucratised public sector (Means \& Smith, 1997). This policy essentially channelled public sector funds into the private institutional sector while leaving the domiciliary sector chronically under-resourced and led to a "perverse incentive" that undermined the commitment to community-based care. Private residential homes flourished and in the absence of community services, older people as "consumers" had little "choice" other than the decision about which institution they might enter in the "residential private sector ple".

Community care has been used as a vehicle for the marketisation of the public sector. Thus, a "contract culture" was to be applied to the provision of personal social services and social services departments would need to develop processes to specify, commission and monitor services delivered by other agencies. The organisation of service delivery was to be instigated through assessment and care management including devolved budgets and decentralisation (Powell, 2010).

Care managers were seen as central in this process. Yet the political issues for care managers to implement community care policy has not focused at all on managing users groups with leaderships sensitised to diversity. Worse, is that the trust process has become in policy-practice-theory matrix so broken it requires a novel way of theorizing trust to help bind professionals and users to each other to help leadership and communication flourish otherwise a fragmented community care system will further fragment the broken relations between managers and users in the UK. Managing diversity requires diverse understanding of different levels of trust.

\section{Navigating Trust in Care Management with Users: Individuals, Organisations, Community and Systems}

The first key focus for theorising trust has been the interpersonal qualities of the individuals involved. Sztompka (1999) challenges theorists who consider interpersonal forms of trust as the primary form based on face-to-face encounters while subordinating all other forms of trust, collectively referred to as social trust. Rejecting any differentiation between interpersonal trust and social forms of trust, he proposes that the ever-increasing impersonal nature of relationships in systems is underpinned by our experiences of trust in face-to-face relations between care managers and users. This reliance on the interpersonal aspect of trust suffers from similar problems to Giddens (1990) use of "ontological security", a product of early childhood experiences, as a prerequisite for individuals being able to form trusting relationships. This conservative element leaves those without positive childhood experiences stuck in a psy- choanalytic mire with no potential for trusting, or by implication being trustworthy, while also failing to offer any means of recovery. A number of theorists (Davies, 1999; Giddens, 1991; Mechanic, 1998) note the expectations lay people have of experts or professionals while at the same time this interpersonal level provides the human aspect or "facework" for more impersonal forms of trust. Expectations of professionals include the following: specific competencies, specialised areas of knowledge and skills, disinterestedness and disclosure. Of particular importance are communication skills and the ability to present complex information. Alongside, run role expectations that demand experts act ethically and with integrity as true agents of their clients, requiring them to put personal beliefs and interests aside and acting to maximise benefit and to do no harm. Creating specialized spaces reinforced by fiduciary norms arising from: the custody and discretion over property, the opportunity and possession of expertise and the access to information; regulates the power/knowledge relationship between expertise and laypersons (Giddens, 1991; Shapiro, 1987).

The second level of trust is at community level. Evidence exists of a positive correlation between levels of interpersonal trust and levels of social capital (Putman, 1993; Rothstein, 2000), leading in part to calls for increasing the levels of civility and community responsibility in everyday life. However, while theorists (Misztal, 1996; Putman, 1993; Taylor-Gooby, 1999, 2000; Sztompka, 1999; Rothstein, 2000; Dean, 2003) support the idea of social norms and values overriding rational models of human behaviour, they say little about how these norms and values become established. Rothstein claims that the link between interpersonal trust and social capital is weak, as are propositions about the direction of community relationships in managing diversity - care managers are bound up in this process. Rejecting functionalist explanations linking norms to the established configurations of power, he proposes a theory of "collective memories" creating social norms in communities as a strategic political process. The essential ingredient is the creation of conditions of community relationships built on common values and aims of both care managers and users in communities.

The third key issue is on trust and organisational context. Challenges to the "trustworthiness" in organisations, regardless of whether they are public or third sector organisations, can have profound effects on confidence in that system. Producing increased demands for regulation, information and transparency; that is, increasing the demands for distrust. Community care organisations are central to this and need to facilitate trust so that interactions with users are transparent and trust facilitated.

The fourth major area of concern for theorising trust has focussed on the declining trust in both state mediated social systems such health and social care and the professions embedded therein (Davies, 1999; Phillipson, 1998; Welsh \& Pringle, 2001). Conceived as impersonal or systems trust (Giddens, 1990, 1991; Luhmann, 1979) this form of trust is developed and maintained by embedding expertise in systems that do not require the personal knowledge of any individual by another. Such systems employ a range of techniques of distrust i.e. audit processes, target setting and third party inspections (Gilbert, 1998, 2005) which could alienate professionals and users.

\section{Implications of Trust in Community Care}

Part of the confusion concerning the different levels of trust 
rests, according to Möllering (2001), with the failure to distinguish between the functional properties of trust and the foundations of how trust is created in community care. The former are the outcomes of trust i.e. expectations, concerning issues such as: order, co-operation, reducing complexity and social capital. While the latter concern the nature or bases of trust, which, due to the assumption that they are rational, become lost and therefore not explored. Moreover, individuals make decisions on partial knowledge, a mix of weak inductive knowledge and faith regarding the consequences of an action. Möllering suggests that in some circumstances relational aspects producing either confidence or reciprocity might support decision-making. However, this knowledge moves us close to confidence, which according to Seligman's (1997) is a different quality. Nevertheless, building on Möllering's theory, Brownlie and Howson (2005) argue that trust is relational and impossible to understand in isolation. Trust occurs as individuals extract the known factors while bracketing off or suspending the unknown factors to avoid confusing decisions with uncertainty.

Gilson (2003) takes up this relational aspect of trust and claims that relationship issues provide the main challenges for community care practices and services. Making the link between systems and social capital, she compares UK and US health care systems. Concluding that the general acceptance by the UK population of the altruistic element of the UK health system stands in stark contrast with the distrust, which accompanies health care in the USA where there is a belief that the system is organised to maximize the benefits for the medical profession. Gilson argues that trust involves both cognitive and affective elements. The former relates to a risk calculation where the costs and benefits of an action are calculated alongside of the degree of uncertainty derived from the dependency on the actions and intentions of another while the latter is linked to the generation of emotional bonds and obligations. Altruism provides a special case of trust where trusting and trustworthiness promote the social status of those involved in giving thus enhancing trust relations between care managers and users.

Other writers draw distinctions between trust and hope. Both Sztompka (1999) and Gilbert (1998, 2005) discuss trust and hope, with hope representing a situation of relative powerlessness, a situation exemplified by Gilbert who concludes that trust is a discourse of professionals and experts while hope is a user discourse. Seligman argues that trust, conceived as it is in this debate, is unique to modernity. In traditional societies, trust has quite different bases. Moreover, sociological theories, which suppose a general change in modernity (cf. Beck, 1992; Giddens, 1994), assume that with the erosion of traditional institutions and scientific knowledge trust becomes an issue more often produced actively by individuals than institutionally guaranteed. To resolve these tensions we propose Foucault's Governmentality thesis as the means to identify the role of trust, along with the mechanisms for the deployment of trust and the role of professional expertise. Social institutions such as community care disseminate a particular ethic of the self into the discrete corners of everyday lives of the population. Supported by a discursive framework promoting co-operative relations between people, communities and organisations this ethic is future orientated and promotes qualities and values that sustain trust-based relationships and forms of action. In the process of building co-operative relations, the role of professionals and professional authority is established. The next section carefully examines the conceptual possibilities for articulation of trust and governmentality.

\section{Linking Care Management with Trust and Govern- mentality}

Conceptually there are tensions but also interesting theoretical possibilities between late [high] modern and post-structuralist conceptions of society. Both identify the fragmentation of traditional forms of authority and expertise, and acknowledge the increasing complexity this produces through the availability of multiple sources of information and different lifestyle choices. As noted earlier late [high] modern conceptions of trust, acknowledge uncertainty and risk as the basis for necessitating trust and point to the failure of rational choice theories as evidence of the existence of social trust. Likewise, governmentality theorists, discuss risk and uncertainty at length (Rose, 1996, 1999; Osborne, 1997; Petersen, 1997), but leave the discussion of [social] "trust" to an observation that trust, traditionally placed in authority figures, has been replaced by audit (Rose, 1999). The problem of creating co-operative relations between individuals and within groups and communities, both in the present and for the future, is left unresolved. Foucault's summary of the working of the state provides a useful starting point for this discussion:

"It is the tactics of government which make possible the continual definition and redefinition of what is within the competence of the State and what is not, the public versus the private, and so on; thus the State can only be understood in its survival and its limits on the basis of the general tactics of governmentality." (Foucault, 1979, p. 21).

Our contention is that the "governmentality thesis" as it has been developed by writers such as: Rose and Miller (1992), Burchell (1991), Rose (1996, 1999), Osborne (1997), Petersen (1997) holds the potential to overcome many of the problems experienced in theorising trust. It provides a means of extending the critical debate over trust. Linking discussions concerning the bases of trust: the conditions Möllering (2001) describes as essential for trust to happen with discussions focusing on the outcomes of trust i.e. social capital, systems or impersonal trust and interpersonal trust (Putnam, 1993; Seligman, 1997; Luhmann, 1979; Giddens, 1990, 1991; Sztompka, 1999; Rothstein, 2000).

Moreover, governmentality provides the means for identifying the mechanisms for deploying particular rationalities across the social fabric. In particular, the interplay between state intervention and the population that institutionalizes expertise as a conduit for the exercise of power in modern societies (Johnson, 2001). Institutionalizing expertise establishes a range of specialized spaces: at once both hidden and visible, providing opportunities across the social landscape for a range of care managers. Experts who work on individuals inciting selfforming activity and individual agency, producing the selfmanaging citizen central to neo-liberal forms of government, "enterprising subjects" or what Burchell (1991, p. 276) terms "responsibilisation". Thus enabling an explanation of trust that avoids resorting to a functionalist argument or an overly deterministic approach limited to either class action or the meaning-giving subject. Furthermore, governmentality can overcome the condition laid by Sztompka (1999) that trust cannot exist in 
conditions of discontinuous change. Indeed, in the context of discontinuous change, particular rationalities and their associated technologies become politicized, leading to increased conflict in the relationship between the state and expertise making trust an evermore valuable commodity.

In analysing the activities of government, Rose and Miller (1992, p. 175) argue, we must investigate "political rationalities" and technologies of government - "the complex of mundane programmes, calculations, techniques, apparatuses, documents and procedures through which authorities seek to embody and give effect to governmental ambitions". In this case, rationalities, operating as discourses and social practices embodying a particular practical ethic, work to reproduce the norms, values and obligations associated with trust. Producing a subject position that values trustworthiness as both a personal characteristic and a characteristic sought in others. Both experts/professionals and the user/customer of health services emerge as the self-managing ethical subjects of neo-liberal rule (Miller, 1993; Davidson, 1994; Rose, 1999).

For governmentality theorists an analysis of neo-liberal regimes reveals individuals as inculcated with values and objectives, orientated towards incorporating people as both players and partners in marketised systems including health and social care. Participation in markets along with the potential for unbounded choice are inextricably entwined with a creative tension, an ethical incompleteness, where private [selfish] desire and public [selfless] obligation produce the rational self-managing actor of neo-liberal rule. In a dialectical relationship that works to form individual identity through the exercise of a modern consumerist citizenship (Miller, 1993). Such regimes exhort individuals; indeed expect them to become entrepreneurs in all spheres, and to accept responsibility for the management of 'risk'. Government is concerned with managing the conduct of conduct, the processes through which people 'govern' themselves, which includes an obligation to manage one's own health (Petersen, 1997).

Theorists of modernity such as Putman (1993), Sztompka (1999) and Rothstein (2000) leave trust to arise organically through the interaction of individuals within groups and communities. The idea that increasing the levels of social interaction to effect a positive consequence on the levels of social and individual trust has a benign attraction, but it tells us little about how or why these norms, values and obligations associated with trust exist in the first place. Alternatively, the analysis of governmentality recognizes these discourses and social practices as the outcome of something more ordered. Not ordered in the sense of designed and managed but the consequence of what Foucault described as strategy: loosely connected sets of discourses and practices that follow a broad trajectory with no necessary correspondence between the different elements (Dreyfus \& Rabinow, 1982).

One tactic, increasingly used within the strategy of government as they struggle with the challenge of managing populations across an ever more complex range of social contexts, is the promotion of co-operative relations within different programmes and technologies. This works to promote, establish and maintain an ethic of co-operation and trustworthiness producing the trusting subject as a version of the disciplined subject, socially valued and malleable. Evidence of this can be found in a range of policy initiatives disseminated by national and local government drawing on communitarian discourses and including an endless array of devices promoting partnerships and active citizenship e.g. Caring about Carers (DoH, 1999), Choosing Health (DoH, 2004), Independence, Wellbeing and Choice (DoH, 2005). Devices targeting communities and neighbourhoods through initiatives promoting community activities often focussed on a variety of locally based independent and autonomous groups. In areas where co-operative relations have failed and require rebuilding the deployment of discourses of empowerment is evident, inciting "damaged subjects" to self-manage (Rose, 1996). Located in initiatives such as Health Action Zones, Community Development Projects and Public Health activities a range of experts and lay volunteers work on individuals encouraging them to take responsibility for their health and engage in self-forming activities, self-care and self-help (Rose, 1999).

Alongside this promotion of co-operative relationships, neoliberal rule increasingly repositions the state as the co-ordinator of activity rather than the provider [cf. Modernising Social Services (DoH, 1998), Every Child Matters (DoH, 2003b), Choosing Health (DoH, 2004) and Independence, Well-being and Choice (DoH, 2005)], progressively drawing communities into the provision of welfare and the management of social problems (Clarke \& Newman, 1997; Rose, 1996, 1999). New, often contradictory, rationalities of competition and co-operation, of participation and consumerism, substitute for earlier forms of public provision. Nevertheless, these contradictory rationalities maintain sufficient coherence to provide the basis for state intervention through professional and lay activity.

One such example is the restructured relationship between the private health sector and the British National Health Service [NHS] (DoH, 2002; Lewis \& Gillam, 2003). Until recently, the private health sector distanced itself from the NHS arguing quality and choice while those committed to a public health service rejected private sector values. Now, a range of policy initiatives such as the use of private sector surgical facilities, the ability to have particular treatments at a facility chosen by the patient (DoH, 2003a) and Private Finance Initiatives [PFIs] have blurred the boundaries between the public and private health sectors. Fixing large sections of the private sector as the reserve capacity of the NHS expanding and contracting on demand without the political consequences of public hospital closures. Furthermore, the use of private capital shifts fiscal liabilities from the present to the future while at the same time distancing the state from responsibility for the maintenance and refurbishment of hospital and other health service facilities and equipment.

Such developments suggest a re-articulation of the discursive structure of private, voluntary and statutory sector organisations in what Clarke and Newman (1997) describe as processes of colonisation and accommodation. Alongside State interventions aimed at provoking co-operative and trust-based relationships, such movements point to the way major institutions of society can become repositories of trust, providing both the example and the experience of trusting while also building the capacity for trust-based relationships across the social fabric. However, in contrast to functionalist conceptions of social institutions as repositories of trust e.g. Misztal (1996), we need to identify the dynamic interplay between the state and the means of intervention at its disposal.

The challenges faced by the state over the last twenty-five years or so such as the increasing health costs of an ageing 
population (Rose, 1999; DoH, 2005) have been matched by rapid social change. One effect of this has been the fragmentation of welfare away from a monolithic state organisation to one co-ordinated and financed by the state but disciplined by market mechanisms such as commissioning and competitive tendering (Clarke \& Newman, 1997; Lewis \& Gillam, 2003). Another effect has been the politicization of the technical i.e. professional expertise (Johnson, 2001), where a variety of forms of expertise competes for dominance. Under such conditions, trust is also politicized (Gilbert, 1998). Trust becomes a commodity for exchange (Dasgupta, 1988). Demanding new forms of governance and producing a paradox, autonomy for organisations and professionals released from direct management by the state is matched by ever more-complex forms of surveillance and control (Rose, 1999; Gilbert, 2001).

Since the 1980 s, claims of a decline in the authority of the professions accompanied this process. Public perceptions of failures of professional self-regulation articulate as institutionalized self-interest (Davies, 2000), paralleled by the increasing power, or resistance, of health service users and welfare consumers to discipline professional activity. Managerialist techniques such as contracts and demands for transparency in exchanges unite managerial and user based discourses in an uncomfortable marriage (Rose, 1999; Shaw, 2001; Stewart \& Wisniewski, 2004; McIvor et al., 2002), frustrating the radical voice of user movements (Clarke \& Newman, 1997). Alongside, a massive increase in the access to the information, particularly through the internet, further complicates the situation. Specialist information, once the sole privilege of the professions, is now widely available, changing the relationship between professionals and laypersons once again challenging professional authority (Hardey, 2005).

For Rose and Miller: "governmentality is intrinsically linked to the activities of expertise, whose role is not weaving an all-pervasive web of 'social control' but of enacting assorted attempts at the calculated administration of diverse aspects of conduct through countless, often competing, local tactics of education, persuasion, inducement, management, incitement, motivation and encouragement" (Rose \& Miller, 1992, p. 175). This web of activity and the specialized spaces created for expertise, work to construct professional authority, condensing the different levels of trust: interpersonal, systems and social capital; into the facework of experts. The fragmentation of expertise, once embedded in the directly managed institutions of the state, has enabled the dispersal of this expertise throughout the third sector leading to a re-articulation of the discourses that support professional activity and trust in expertise.

It is notable that despite the conflicts of the 1980s, the care managerial professions appear to carry on relatively unscathed leading to the conclusion that the decline in the authority, power and popularity of the professions has been overstated. One key factor is that certain tasks and activities demand professional competence especially in circumstances where the outcome cannot be pre-determined (Clarke \& Newman, 1997). Once again, revealing the paradox of autonomy and increasing regulation in the relationship between the state and professional activity. Returning to the earlier quotation from Foucault, what has occurred in this period is the re-articulation of government objectives and a re-structuring of the realms of professional jurisdiction and authority (Johnson, 2001). Regulation and control of expertise through audits and contracts are disciplinary techniques that have modernized the tricky issue of governing professional activity. Accompanied by a re-articulation of professional discourse objectifying the activity of expertise rendering it both manageable (Rose, 1999), and enabling the surveillance of professional activity across a landscape no longer defined by institutions and buildings of the poor law. At the same time policy documents such as "Choosing Health" (DoH, 2004) and Independence, Well-being and Choice (DoH, 2005) are unashamedly consumerist, demonstrating shifts in the way community care is managed.

Central to this process is a paradox where the need for experts to manage complex and unpredictable situations has led to trust in professional autonomy becoming almost exclusively located with the management of risk (Rose, 1996, 1999; Petersen, 1997; Kemshall, 2002). Competence in the management of risk is therefore the central basis, which maintains the professional status of health and social care professionals. Failure in this respect can lead to very public examinations of the competence of individual professionals, in particular where there is danger of a legitimation crisis. Professionals who, despite evidence of system failure, experience a form of symbolic sacrifice and public humiliation, recent examples include Dr Marietta Higgs [Cleveland Child Abuse Inquiry], Lisa Arthurworrey [Victoria Climbie's social worker] (James, 2005) and Professor Sir Roy Meadows [expert witness in child death cases (Laville, 2005)].

Challenges to traditional or institutionalized expertise by new or non-conventional forms of expertise also demonstrates this re-structuring of the objectives of government and the jurisdiction of professionals. Some problems have persistently frustrated traditional forms of expertise in health care and social welfare at the same time widely dispersed and contract based activity enables entry for alternative approaches. Here again the dynamic quality of Governmentality, demonstrates processes of colonisation and accommodation. Lee-Treweek (2002) explores this process in the context of a complementary therapy, cranial osteopathy, describing how traditional medicine accepts elements of complementary practice on condition that the alternative approach accepts particular rituals and the primacy of the existing medical hierarchy. The need to manage chronic conditions such as skeletal and muscular pain, areas where traditional medicine has failed to provide a reliable treatment, enables a new form of expertise to institutionalise itself with the state. Securing trust in this specialized space enables this form of expertise to contest the hegemony of risk to its advantage.

\section{Conclusions}

This article has reviewed the emergence and consolidation of community care policy in the UK and impact on relations between care managers and user groups underpinned by diversity. One of the central problems of facilitating any leadership or rapport for care managers with older people in the UK has been the issue of "trust". As we have seen, here is a multiplicity of ways that trust has been defined but the central paradox is how to creation of the conditions of building conditions of trust across personal-organisational-structural tiers in an increasingly uncertain world. The chapter has assessed community care policy and navigated the ways trust relations can capture stronger bonds and relationships between care managers and user groups such as older people in the UK. This is an immense conceptual and experiential challenge. What emerges is a fusion of consumerist, traditional, alternative and complementary 
discourses articulated with discourses of co-operation, partnership and trust in health and social care providing an matrix of spaces where a wider range of expertise, in both type and numerically, than ever before is embedded. At one level, experts identify risk at the same time as providing a general surveillance of the population, at another level they work within systems legitimated by a myriad of mechanisms of distrust while simultaneously working at another level on individuals to promote a general ethic of trust. Thus, the mechanisms constructing the contemporary authority of expertise are established. Managing diversity is inextricably linked to trust. Condensing trust in the facework of care managers places users of health and social care in a dynamic context. Community care policy continually redefines previous patterns of social relationships both within health and welfare agencies and between those agencies and their customers. Gilbert et al. (2003) identified professionals in health and social care agencies responding to policy pressures by managing the expectations [trust] of different individuals and groups with potentially conflicting interest's e.g. individual users, parents/carers and the local community. These experts engaged in a process of change and consolidation managing conflict while furthering both organisational and political aims related to community care. Hence, this process is needed to be further sustained to have a better understanding of how users and care managers can actually understand, listen and respect each other.

\section{References}

Age Concern England (1997). Age matters: Report on a national Gallup survey. London: ACE.

Allen, C., et al. (1994). Social care in a mixed economy. Milton Keynes: Open University Press.

Allen, I., et al. (1992). Elderly people: Choice, participation and satisfaction. Policy Studies Institute, (PSI).

Audit Commission (1986). Making a reality of community care. PSI, London.

Audit Commission (1996). Balancing the care equation: Progress with Community Care. HMSO, London.

Biggs, S. (1993). Understanding ageing. Milton Keynes: Open University Press.

Biggs, S. \& Powell, J. (2000). Surveillance and elder abuse: The rationalities and technologies of community care. Journal of Contemporary Health, 4, 41-49.

Bond, J. \& Coleman, P. (1990). Ageing in society. London: Sage.

Bone, M. (1996). Trends in dependency among older people in England. OPCS, London.

Bornat, J., et al. (Eds.). (1993). Community care: A reader. Milton Keynes: Open University Press.

Bornat, J. Ed. (1994). Reminiscence reviewed. Milton Keynes: Open University Press.

Bowl, R. (1986). Social work with old people. In C. Phillipson and A. Walker (Eds.), Ageing and Social Policy. London: Gower.

Chau, W. F. (1995). Experts, networks and inscriptions in the fabrication of accounting images. Accounting Organisations and Society, 20 , 111-145. doi:10.1016/0361-3682(95)95744-H

Clarke, J. (1994). Capturing the customer: Consumerism and social welfare, paper to ESRC seminar conceptualising consumption issues. Lancaster: University of Lancaster.

Deakin, N. (1996). The Devils in the detail: Some reflections on contracting for social care. Social Policy and Administration, 30, 20-38. doi:10.1111/j.1467-9515.1996.tb00479.x

Department of Health (1989). Caring for people: Community care in the next decade and beyond, Cm849. London: HMSO.

DoH (1991). Caring for people: Implementation documents, draft guidance: Assessment and care management. London: HMSO.

DoH (1994). Community care packages for older people. London: HMSO.

Du Gay, P. (1996). Consumption and identity. London: Sage.

Fennell, G., et al. (1988). Sociology of age. Buckingham: Open University Press.

Finch, J. (1986). 'Age' in burgess. Key variables in social investigation. London: RKP.

Flynn, R. (1992). Structures of control in health management. London: Routledge.

Fowler, N. (1984). Speech to joint social services annual conference. London: DHSS.

Gabe, J. (1991). The sociology of the health service. London: Routledge. doi: $10.4324 / 9780203404751$

Griffiths, S. R. (1988). Community Care: Agenda for action. London: HMSO.

Henwood, M. (1990). Community care and elderly people, policy, practice and research review. Oxford: Family Policy Studies Centre.

Henwood, M. (1995). Making a difference? London: Nuffield Institute for Health/Kings Fund Centre.

Hills, J. (1993). The future of welfare: A guide to the debate. York: Joseph Rowntree Foundation.

Hockey, J. \& James, A. (1993). Growing up and growing old: Ageing and dependency in the life course. London: Sage.

Hospital Advisory Service (1982). The rising tide: Developing services for mental illness and old age. London: HMSO.

Hughes, B. (1995). Older people and community care: Critical theory and practice. Milton Keynes: Open University Press.

Kiernan, K. \& Wicks, M. (1990). Family change and future policy. York: Joseph Rowntree Memorial Trust.

Levick, P. (1992). The Janus face of community care legislation: An opportunity for radical opportunities. Critical Social Policy, 34, 76-81.

Lewis, J. \& Glennerster, H. (1996). Implementing the new community care. Milton Keynes: Open University Press.

Meredith, B. (1994). The next steps: Lessons for the future of community care. London: ACE.

Phillipson, C. (1982). Capitalism and the construction of old age. London: Macmillan.

Phillipson, C. (1988). Challenging dependency: Towards a new social work with older people. In M. Langan and P. Lee (Eds.), Radical social work today. Boston: Unwin Hyman.

Phillipson, C. \& Walker, A. (Eds.) (1986). Ageing and social policy: A critical assessment. Gower: Aldershot.

Qureshi, H. \& Walker, A. (1989). The caring relationship. London: Macmillan.

Seebohm Committee (1968). Report of the committee on local authority and allied personal social services, Cmnd 3703. London: HMSO.

Smart, B. (1985). Michel foucault. London: Routledge. doi:10.4324/9780203405741

Vincent, J. (1996). Inequality and old age. London: University College London Press.

Walker, A. (1985). The care gap. London: Local Government Information Service.

Walker, A. (1993). Community care policy: From consensus to conflict. In J. Bornat, et al. (Eds.), Community care: A reader. Milton Keynes: Open University Press.

Walsh, K. (1995). Public services and market mechanisms. London: Macmillan.

Wardhaugh, J. \& Wilding, P. (1993). Towards an explanation of the corruption of care. Critical Social Policy, 37, 4-31. doi:10.1177/026101839301303701

Warnes, A. (Ed.) (1996). Human ageing and later life. London: Edward Arnold.

Webb, A. \& Wistow, G. (1987). Social work, social care and social planning: The personal social services since seebohm. London: Longman.

Williams, F. (1994). Social policy: A critical introduction (2nd ed.). Oxford: Blackwell. 